\title{
Tailoring the Functional Potential of Red Beet Purées by Inoculation with Lactic Acid Bacteria and Drying
}

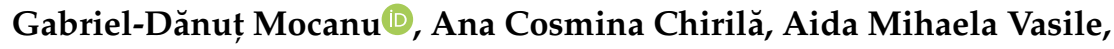 \\ Doina Georgeta Andronoiu, Oana-Viorela Nistor, Vasilica Barbu(10) and Nicoleta Stănciuc *(1) \\ Department of Food Science, Food Engineering, Biotechnology and Aquaculture, Faculty of Food Science \\ and Engineering, “Dunarea de Jos” University of Galați, 800201 Galați, Romania; \\ Danut.Mocanu@ugal.ro (G.-D.M.); cosminachana@gmail.com (A.C.C.); Aida.Vasile@ugal.ro (A.M.V.); \\ Georgeta.Andronoiu@ugal.ro (D.G.A.); Oana.Nistor@ugal.ro (O.-V.N.); Vasilica.Barbu@ugal.ro (V.B.) \\ * Correspondence: Nicoleta.Stanciuc@ugal.ro; Tel.: +4-0336-130-183
}

Received: 16 October 2020; Accepted: 5 November 2020; Published: 6 November 2020

\begin{abstract}
This study was focused on a comparative analysis of two drying methods, such as convective and infrared drying, on the red beetroot purées with lactic acid bacteria, as a strategy for tailoring the health benefits of the selected plant. For both varieties, the total betalain contents varied from $13.95 \pm 0.14 \mathrm{mg} / \mathrm{g}$ dry weight in Beta vulgaris var. cylindra when compared with $11.09 \pm 0.03 \mathrm{mg} / \mathrm{g}$ dry weight in Beta vulgaris var. vulgaris, whereas significant differences were found in total phenolic and flavonoid contents. Significant drying induced changes were found in selected bioactives, in terms of total betalains, flavonoids, and polyphenols, which influenced the antioxidant activities of the purées, structure, and color parameters. In general, infrared technology was more protective, leading to an increase of $20 \%$ in flavonoids content. One logarithmic decrease in cell viability was observed in all powders samples. After the in vitro digestion, the betalains decreased, in both gastric and intestinal simulated juices, with a more pronounced profile in infrared processed purées. Textural and rheological analysis of the dried purées highlighted that the infrared drying is milder compared to the conventional one, allowing us to obtain powders with enhanced functional properties, in terms of bioactives content, cell viability, color, and structural and rheological behavior.
\end{abstract}

Keywords: beetroot; convective drying; infrared drying; purée; antioxidant activity; Fourier-transform infrared spectroscopy; confocal scanning microscopy; texture

\section{Introduction}

Considered in recent years as key components providing substantial benefits to human health, biologically active compounds, such as polyphenols and betalains, have recently gained particular interest from both academia and relevant industry from the perspective of developing foods and ingredients with positive effects for health [1].

Red beet (Beta vulgaris) are among the most popular varieties of vegetables, not only because of its significant content in biologically active compounds, such as polyphenols and betalains, but also their intense aromatic flavor [2]. Betalains are known as water-soluble nitrogen-containing pigments, consisting of two sub-classes: betacyanins (red-violet pigments) and betaxanthins (yellow-orange pigments) [3]. The health benefits of betalains are described as antimicrobial [4], inhibition of cell proliferation of human tumor cells [5], prevention of diseases like cancer, cardiovascular diseases [6], anti-inflammatory effects, antiradical and antioxidant activity [7], and enriching human low-density lipoproteins, which increase resistance to oxidation [8].

It is well known that color is an important quality indicator that determines the consumers' acceptance of foods. A more extensive application of natural colorants over synthetic ones has been 
observed recently on the market, especially because natural coloring is commonly associated with positive effects on human health and can also be used as functional additives. The use of pigments from a natural origin is usually limited due to their low stability, solubility, bioavailability, interaction with other components of the food matrix, etc. [9]. From the perspective of developing food products with enhanced properties, from both nutritional and functional point of view, it is necessary to choose appropriate methods for obtaining and stabilizing these valuable compounds.

Several colorants may be used for coloring foods, such as anthocyanins and carotenoids. The use of betalains for coloring food products is approved by the European Union and betalains are labeled as E-162; however, the use of betalains for specific uses provide several advantages, since these pigments, having the ability to cover a wide color range, from red to purple, are considered to be more stable to $\mathrm{pH}$ and temperature-induced changes. Due to the higher stability in a wider $\mathrm{pH}$ range, the use of betalains as a dye allows the replacement of anthocyanins for low-acid foods [3]. When comparing to carotenoids, which exhibit a yellow-orange color range, their applications are limited due to poor solubility in water; however, betaxanthins could be successfully used in application as yellow-orange food colorants [10].

Drying is a classical method of food preservation, providing several advantages such as smaller space for storage, lighter weight for transportation, and longer shelf-life [11]. Additionally, dried vegetables may be used as ingredients in ready-to-eat meals in order to add value by improving their functional quality due to health benefit compounds (vitamins, phytochemicals, and dietary fibers), and therefore, drying methods have acquired particular importance from the perspective of selecting methods that preserve the untainted qualities of the products [12]. One of the most used methods for drying vegetables and fruits is convective drying, which uses hot air to heat and remove water from the product [13].

The infrared assisted drying technology is one of the growingly popular approaches to provide heat for the drying of moist materials [14], allowing infrared radiation energy to be transmitted from the heating agent to the product. The technology brings some advantages, such as quick and homogeneous heating of the material without heating the surrounding air [15] where the generated heat in a layer below the surface is transferred to the material's center and surface. Additionally, due to the moisture transfer from the material's center to the surface, the heat and mass transfers are concurrent and countercurrent in layers, close to the material's surface and its other parts, respectively [16].

The main objective of this study was the comparative analysis of two techniques for drying red beetroot purées, impregnated with lactic acid bacteria to obtain powders with functional potential. Two drying methods were used: convective and infrared assisted drying methods. The red beetroot purées were analyzed for betalains content, antioxidant activity, cell viability, color, and in vitro release of total betalains. The structural and morphological particularities of the powders after drying were analyzed by using confocal laser microscopy. The drying induced changes in powders were analyzed by Fourier transform infrared spectroscopy (FT-IR). Textural properties and non-linear viscoelastic behavior were also analyzed for the rheological characterization of the powders.

\section{Materials and Methods}

\subsection{Plant Materials}

Two types of fresh red beet (taproots of Beta vulgaris L. var. vulgaris and Beta vulgaris L. var. cylindra) were obtained from the local vegetable market in Galați, Romania respectively Cahul, Republic of Moldova and stored at $4{ }^{\circ} \mathrm{C}$ before the analysis (not exceeding $48 \mathrm{~h}$ from procurement). The initial moisture content of the samples was $88.05 \pm 0.20 \%$ and $88.17 \pm 0.40 \%$ for Beta vulgaris $\mathrm{L}$. var. vulgaris and Beta vulgaris L. var. cylindra, respectively, while the final moisture content was $8.03 \pm 0.30 \%$ and $8.12 \pm 0.20 \%$. 


\subsection{Lactic Bacteria}

The commercial culture Lactobacillus casei ssp. paracasei (L. casei $431^{\circledR}$ ) was provided by Chr. Hansen (Hoersholm, Denmark).

\subsection{Sample Preparation}

\subsubsection{Inoculum Preparation}

The freeze-dried strain was reactivated in MRS (de Man, Rogosa, and Sharpe agar) broth (Merk, Darmstadt, Germany), at $37{ }^{\circ} \mathrm{C}$ for $24 \mathrm{~h}$ and grown under these conditions until achieving high cell concentration ( $>10^{9} \mathrm{CFU} / \mathrm{mL}$ ). The method described by Begot et al. [17] was used to estimate the bacterial cell concentration by the turbidimetric method. The logarithmic value of bacterial cell concentration was obtained by dilution and pour plate counting after incubation in MRS agar at $37^{\circ} \mathrm{C}$ for $48 \mathrm{~h}$ under aerobic conditions [18].

\subsubsection{Red Beet Pureés Preparation}

Fresh beetroots were washed, peeled, and cut into small pieces. The purée was prepared by blending $1 \mathrm{~kg}$ from each variety of fresh red beet with $87.5 \mathrm{~g}$ of double distilled water for $5 \mathrm{~min}$ using a kitchen blender Philips HR2100/40. An inoculum of $1 \%$ of L. casei $431{ }^{\circledR}$ was added into the purée samples. Six variants of red beet purée were obtained, coded as follows: $\mathrm{BV}_{0}$-fresh sample of Beta vulgaris $\mathrm{L}$. var. vulgaris, $\mathrm{BC}_{0}$-fresh sample of Beta vulgaris $\mathrm{L}$. var. cylindra, $\mathrm{BV}_{\mathrm{C}}, \mathrm{BC}_{\mathrm{C}}$-red beet purée dried by convection method, $\mathrm{BV}_{\mathrm{IR}}, \mathrm{BC}_{\mathrm{IR}}$-red beet purée dried by infra-red (IR) method.

\subsection{Drying of the Samples}

Drying experiments were carried out in an oven dryer with 5 perforated trays (mesh trays) (Concept SO4000 Infra 500W, Chocen, Czech Republic). The red beet purée samples were placed on a stainless steel tray with a surface area of $0.072 \mathrm{~m}^{2}$. To ensure the optimal parameters of the drying process, the dryer was preheated for $1 \mathrm{~h}$ before use. The red beet purée (approximately $350 \mathrm{~g}$ for each variant) was spread on the tray surface obtaining a $1.5 \mathrm{~mm}$ thick layer using a digital micrometer. The layer thickness was measured in five points of the baking paper (in the four corners and the middle). The drying experiment was performed at a constant air velocity of $1.1 \mathrm{~m} \cdot \mathrm{s}^{-1}$, a relative humidity of $11.2 \%$, and a drying temperature of $45^{\circ} \mathrm{C}$, while the ambient air temperature was $20^{\circ} \mathrm{C}$. The air velocity was measured with a VT 115 hotwire thermo-anemometer (Kimo Instruments, Millgrove, Ontario, Canada). The relative humidity was measured with a thermo hygrometer EE33 Series, fitted with a sensing probe (E + E Electronik Ges.m.b.H. Engerwitzdorf, Austria). The drying of red beet purée samples was carried out until the equilibrium humidity ( $3 \mathrm{~h}$ and $30 \mathrm{~min}$ in the case of convective drying and $2 \mathrm{~h}$ and $30 \mathrm{~min}$ for infrared drying). After each drying experiments, all the samples were cooled under laboratory conditions and stored in airtight containers. All drying experiments were performed in triplicate.

\subsection{Extraction of Betalains}

The extraction step of betalains was performed as described by Ravichandran et al. [19]. Briefly, $0.1 \mathrm{~g}$ of dried samples were mixed with $10 \mathrm{~mL}$ of $50 \%$ ethanol, agitated for $10 \mathrm{~s}$, followed by centrifugation at $6000 \times g$ for $10 \mathrm{~min}$. To increase the yield of betalains extraction, the supernatant was collected, and the extraction was repeated 3 more times. The supernatant was further used for the determination of betalains.

\subsection{Determination of Betalain Compounds by Spectrophotometric Methods}

The content of betaxanthins and betacyanins in the extracts was determined spectrophotometrically at 538 and $480 \mathrm{~nm}$ with a UV-Vis spectrometer. 
The total betalain content $(B C)$ was calculated using Equation (1):

$$
B C\left(\frac{m g}{g}\right)=\frac{A \cdot D F \cdot M_{w} \cdot 1000}{\operatorname{ex1}}
$$

where $A$ is the absorption, $D F$ the dilution factor, and 1 the pathlength $(1 \mathrm{~cm})$ of the cuvette. For quantification of betacyanins and betaxanthins, the molecular weights $\left(M_{w}\right)$ and molar extinction

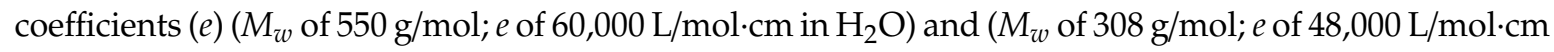
in $\mathrm{H}_{2} \mathrm{O}$ ) were applied.

\subsection{Antioxidant Activity}

The antioxidant activity of the ultrasound-assisted extracts dissolved in ethyl acetate was measured by using the modified ABTS (2,2'-Azino-bis(3-ethylbenzothiazoline-6-sulfonic acid) radical decolorization assay according to the method described by Miller and Rice-Evans [20]. The experiments were performed in triplicate.

\subsection{Cells Viability}

For viable cell counting of L. casei $4311^{\circledR}, 10$-fold serial dilutions of the samples were performed using sterile physiological serum $(0.9 \mathrm{~g} \mathrm{NaCL} \%, w / v)$. The pour plate technique was employed. The viable cell number was determined by estimating the number of colony-forming units on the MRS-agar plates after incubation at $37^{\circ} \mathrm{C}$ for $48 \mathrm{~h}$. The counts were expressed as colony-forming units per gram. The viability of L. casei $431{ }^{\circledR}$ was determined immediately after manufacturing and during storage at 7,14 , and 21 days.

\subsection{In Vitro Release of the Betalains}

The protocol described by Oancea et al. [21] was used to perform red beetroot dried purées to a simulated in vitro gastrointestinal digestion process, mimicking gastric and intestinal phases. The post-hydrolysis fractions were collected at every $30 \mathrm{~min}$ of digestion, centrifuged $(10,000 \times g$ for $10 \mathrm{~min}$ ), and analyzed for betalains content.

\subsection{Color Parameters}

The color parameters of fresh and dried samples were performed using a MINOLTA Chroma Meter CR-410 (Konica Minolta, Osaka, Japan). For color analysis, it is necessary to have a homogeneous powder the dried samples were ground for $20 \mathrm{~s}$ with a grinder (Gorenje SMK150B, Velenje, Republic of Slovenia). To obtain fresh red beetroot puree, the red beet was blended at $1900 \mathrm{rpm}$ for $3 \mathrm{~min}$ with a laboratory blender (Philips HR2100/40, EC) to achieve a uniform color. The color parameters determined for fresh and dried red beetroot were $L^{*}$ (lightness/darkness), $a^{*}$ (red/green), and $b^{*}$ (yellow/blue). The total color difference $(\Delta E)$ between samples was calculated according to Equation (2) [22]:

$$
\Delta E=\sqrt{\left(L_{0}^{*}-L^{*}\right)^{2}+\left(a_{0}^{*}-a^{*}\right)^{2}+\left(b_{0}^{*}-b^{*}\right)^{2}}
$$

Subscript 0 refers to the color of the fresh sample. The color intensity $\left(C^{*}\right)$ and visual color appearance $\left(h^{*}\right)$ were calculated according to Equations (3) and (4) [22]:

$$
\begin{aligned}
& C^{*}=\sqrt{a^{* 2}+b^{* 2}} \\
& h^{*}=\tan ^{-1}\left(\frac{b^{*}}{a^{*}}\right)
\end{aligned}
$$


$L^{*}, a^{*}, b^{*}$ values were used to establish the whiteness index according to the following Equation (5) [23]:

$$
W I=100-\left[\left(100-L^{*}\right)^{2}+a^{* 2}+b^{* 2}\right]^{1 / 2}
$$

According to Maskan [24] the browning index (BI) and the yellowness index (YI) were calculated using Equations (6) and (7):

$$
B I=100 \times\left(\frac{X-0.31}{0.17}\right)
$$

where

$$
X=\frac{\left(a^{*}+1.75 \cdot L^{*}\right)}{\left(5.645 \cdot L^{*}+a^{*}-3.012 \cdot \hat{b}\right)} \text { and } Y I=\frac{142.86 \cdot b^{*}}{L^{*}}
$$

The color parameters are dimensionless. The color analysis was performed in triplicate.

\subsection{Structural and Morphological Properties of the Dried Powders}

To highlight the functional potential of red beet purées inoculated with L. casei 431 strain, the confocal laser scanning microscopy (CLSM) analysis was performed using an LSM 710 system (Carl Zeiss MicroImagining, Göttingen, Germany) equipped with a diode laser (405 nm), Ar-laser (458 nm, $488 \mathrm{~nm}, 514 \mathrm{~nm}$ ), diode-pumped solid-state laser (DPSS; $561 \mathrm{~nm}$ ) and HeNe-laser (633 nm). The 3D images were acquired with an AxioObserver Z1 inverted microscope (20x apochromatic objective, numerical aperture 1.4) and analyzed by ZEN 2012 SP1 software (black edition; Carl Zeiss MicroImagining, Göttingen, Germany). The autofluorescence of the samples was captured in the range of 500-660 $\mathrm{nm}$ wavelengths (emission spectrum of betalains) [25]. The acquisition parameters of the images were: mean method, line scan mode, speed 6, and 12-bit depth. In order to increase the signal-to-noise ratio, a frame average of eight scans was used.

\subsection{FT-IR}

The infrared spectra were collected using a Nicolet iS50 FT-IR spectrometer (Thermo Scientific, Waltham, MA, USA) equipped with a built-in ATR (Attenuated Total Reflectance) accessory, DTGS (Deuterated Triglycine Sulfate) detector, and KBr beam splitter. 32 scans were co-added over the range of $4000-400 \mathrm{~cm}^{-1}$ with a resolution of $4 \mathrm{~cm}^{-1}$. Air was taken as the reference for the background spectrum before each sample. After each spectrum, the ATR plate was cleaned with ethanol solution. In order to verify that no residue from the previous sample remained, a background spectrum was collected each time and compared to the previous background spectrum. The FT-IR spectrometer was sited in a room that was air-conditioned with controlled temperature $\left(21^{\circ} \mathrm{C}\right)$.

\subsection{Textural and Oscillatory Measurements}

\subsubsection{Texture Analysis}

Fresh and reconstituted beetroot purée samples were poured into cylindrical plastic containers with $40 \mathrm{~mm}$ diameter and $50 \mathrm{~mm}$ length so that the height of the samples was $40 \mathrm{~mm}$. A double penetration test was applied, using a $25.4 \mathrm{~mm}$ acrylic cylinder of a Brookfield CT3 texture analyzer (AMETEK Brookfield, Middleboro, MA, USA). The testing parameters were set as follows: target distance $10 \mathrm{~mm}$, trigger load $0.067 \mathrm{~N}$, pretest speed $2 \mathrm{~mm} / \mathrm{s}$, test speed $1 \mathrm{~mm} / \mathrm{s}$, return speed $1 \mathrm{~mm} / \mathrm{s}$, and load cell $1000 \mathrm{~g}$. The textural parameters (firmness, adhesiveness, cohesiveness, and springiness) were determined with TexturePro CT V1.5 software, provided by Brookfield Engineering Labs. Inc., (Middleborough, MA, USA).

\subsubsection{Rheological Analysis}

The rheological analysis was performed with an AR2000ex controlled rheometer (TA Instruments, New Castle, DE, USA). Firstly, to identify the linear viscoelastic region, a strain sweep test was applied, 
maintaining a frequency of $1 \mathrm{~Hz}$ and varying the strain between 0.01 and $100 \%$. Then, a dynamic frequency sweep test was applied, between 0.1 and $100 \mathrm{~Hz}$, at a constant strain of $0.2 \mathrm{~Hz}$. In all cases, storage modulus $\left(\mathrm{G}^{\prime}\right)$ and loss modulus $\left(\mathrm{G}^{\prime \prime}\right)$ were registered. All the measurements were made at $25^{\circ} \mathrm{C}$, with a $40 \mathrm{~mm}$ diameter geometry and o closure gap of $2 \mathrm{~mm}$.

\subsection{Statistical Analysis}

All analyses were performed in triplicate and data reported as mean \pm standard deviation (SD). To identify significant differences, experimental data were subjected to one-way analysis of variance (ANOVA) after running the normality and homoscedasticity tests. The Tukey method with a 95\% confidence interval was employed for post-hoc analysis; $p<0.05$ was considered to be statistically significant. The statistical analysis was carried out using Minitab 18 software.

\section{Results and Discussion}

\subsection{The Content of Selected Phytochemicals in Fresh Red Beet Purées}

Initially, the betalains content of the fresh red beet pureés was measured by using spectrophotometric methods. A significantly $(p<0.05)$ higher content of total betalains was found in $\mathrm{BC}_{0}$ pureés of $13.95 \pm 0.14 \mathrm{mg} / \mathrm{g}$ DW when compared with $11.09 \pm 0.03 \mathrm{mg} / \mathrm{g} \mathrm{DW}$ in $\mathrm{BV}_{0}$. Both varieties showed (Table 1) a similar content in betaxanthins, of $4.71 \pm 0.06 \mathrm{mg} / \mathrm{g}$ DW and $4.06 \pm 0.01 \mathrm{mg} / \mathrm{g}$ DW, whereas significant differences $(p<0.05)$ were found in betacyanins, with $9.23 \pm 0.07 \mathrm{mg} / \mathrm{g}$ DW and $7.03 \pm 0.02 \mathrm{mg} / \mathrm{g} \mathrm{DW}$, respectively. The total polyphenolic content (TPC) showed significant differences $(p<0.05)$, with a more than two-twice higher concentration of total polyphenols in $\mathrm{BC}_{0}$ (71.94 $\pm 2.21 \mathrm{mg} \mathrm{GAE} / \mathrm{g} \mathrm{DW})$ when compared with $\mathrm{BV}_{0}(32.88 \pm 0.34 \mathrm{mg} \mathrm{GAE} / \mathrm{g} \mathrm{DW})$. Total flavonoids were found in a higher concentration in $\mathrm{BV}_{0}$ of $36.00 \pm 1.78 \mathrm{mg} \mathrm{CE} / \mathrm{g} \mathrm{DW}$, when compared with $23.31 \pm 1.34 \mathrm{mg} \mathrm{CE} / \mathrm{g} \mathrm{DW}$ in $\mathrm{BC}_{0}$. The antioxidant profile showed significant differences $(p<0.05)$, with values of $93.46 \pm 2.51 \mathrm{mMol}$ Trolox/g DW in $\mathrm{BC}_{0}$ and a lower value in $\mathrm{BV}_{0}$ of $53.94 \pm 2.87 \mathrm{mMol}$ Trolox/g DW, suggesting that the betacyanins and polyphenols were the primary compounds responsible for antioxidant activity. The global phytochemical profile of the two varieties studied may be a result of varietal diversity, the influence of vegetation season, as well as climatic and cultivation conditions [26].

Table 1. Phytochemical profile of fresh and dried red beetroot purées.

\begin{tabular}{|c|c|c|c|c|c|}
\hline Samples Code & \multicolumn{2}{|c|}{ Betalains } & $\begin{array}{c}\text { Total Polyphenols, } \\
\text { mg GAE/g DW }\end{array}$ & $\begin{array}{c}\text { Total Flavonoids, } \\
\text { mg EC/g DW }\end{array}$ & $\begin{array}{c}\text { ABTS Radical } \\
\text { Scavenging Activity, } \\
\text { mMol Trolox/g DW }\end{array}$ \\
\hline $\mathrm{BC}_{0}$ & $9.23 \pm 0.07^{C}$ & $4.71 \pm 0.06^{C}$ & $71.94 \pm 2.21^{\mathrm{B}}$ & $36.00 \pm 1.78^{B, C}$ & $93.46 \pm 2.51 \mathrm{~A}$ \\
\hline $\mathrm{BV}_{\mathrm{C}}$ & $4.25 \pm 0.02^{C}$ & $2.53 \pm 0.02^{C}$ & $29.01 \pm 0.97^{\text {B }}$ & $16.22 \pm 0.81^{\mathrm{B}, \mathrm{C}}$ & $26.19 \pm 0.32^{\mathrm{A}}$ \\
\hline $\mathrm{BC}_{\mathrm{C}}$ & $4.19 \pm 0.02^{C}$ & $2.21 \pm 0.01^{C}$ & $26.05 \pm 0.24^{\mathrm{B}}$ & $14.02 \pm 0.49^{\mathrm{B}, \mathrm{C}}$ & $55.95 \pm 0.57^{\mathrm{A}}$ \\
\hline $\mathrm{BC}_{\mathrm{IR}}$ & $4.29 \pm 0.02 \mathrm{C}$ & $2.60 \pm 0,08^{C}$ & $26.47 \pm 1.18^{B}$ & $27.06 \pm 1.57^{B, C}$ & $94.21 \pm 0.38^{\mathrm{A}}$ \\
\hline
\end{tabular}

$\mathrm{BV}_{0}$-fresh sample of Beta vulgaris $\mathrm{L}$. var. vulgaris; $\mathrm{BC}_{0}$-fresh sample of Beta vulgaris $\mathrm{L}$. var. cylindra; $\mathrm{BV}_{\mathrm{C}}, \mathrm{BC}_{\mathrm{C}}-\mathrm{red}$ beet purée dried by convection method; $\mathrm{BV}_{\mathrm{IR}}, \mathrm{BC}_{\mathrm{IR}}$-red beet purée dried by IR method. Means that do not share a letter as a superscript $(\mathrm{A}, \mathrm{B}, \mathrm{C})$ are significantly different.

Regarding the individual betalains, Sawicki et al. [27] studied thirteen varieties and root parts of red beet and identified betanin and isobetanin from betacyanin group and vulgaxanthin I from betaxanthins as the major compounds. These authors reported betaxanthins levels ranging from 2.71 to $4.25 \mathrm{mg} / \mathrm{g} \mathrm{DW}$, whereas betacyanins content varied between 8.30 and $13.50 \mathrm{mg} / \mathrm{g}$ DW. The scavenging capacity of red beetroot varieties determined by the ABTS assay was found by these authors within the range from 37.68 to $49.71 \mathrm{~mol}$ Trolox/g DW, being positively correlated with the total betalain and betacyanin contents. In some other studies, it has been reported that the concentrations of betacyanins and betaxanthins in the roots of red beet varied from 400 and $2100 \mathrm{mg} / \mathrm{kg}$ fresh weight and between 
200 and $1400 \mathrm{mg} / \mathrm{kg}$ fresh weight, respectively [28]. Moreover, the betalain content differs depending on the red beetroot variety $[27,29]$.

\subsection{The Content of Selected Phytochemicals in Dried Red Beet Purées}

It is well known that food drying has as the main purpose the removal of free water from products to a level considered critical for chemical and microbiological reactions while reducing weight and volume, intended to reduce transportation and storage costs [13]. In our study, two drying methods were used for red beetroot purées, namely convective and infrared drying. Following the drying, the phytochemicals profile (Table 1 ) of the resulting powders were analyzed, to evaluate the losses of the main red beet pigments. A significant decrease in total betalains of approximatively $50 \%$ and $43 \%$ were observed in $\mathrm{BV}_{\mathrm{C}}$ and $\mathrm{BC}_{\mathrm{C}}$, respectively. The infrared technology caused a less intense degradation effect in the total betalains content, with approximatively $50 \%$ and $38 \%$ in $\mathrm{BV}_{\mathrm{IR}}$ and $\mathrm{BC}_{\mathrm{IR}}$, respectively.

A comparative analysis of the two drying methods on the betalains showed a more protective effect of the infrared technology, with a decrease of approximately $39 \%$ in $\mathrm{BC}_{\mathrm{IR}}$ and $36 \%$ in $\mathrm{BV}_{\mathrm{IR}}$ for betaxanthins, whereas convection drying leads to a significantly higher decrease of approximately $46 \%$ for both varieties. The convection drying caused a significant decrease in the betacyanin, with $40 \%$ in both varieties, whereas infrared drying leads to a significantly different decrease patterns in the selected purées, with a decrease of $51 \%$ in $\mathrm{BC}_{\mathrm{IR}}$ and approximately $39 \%$ in $\mathrm{BV}_{\mathrm{IR}}$.

Drying by convection of $\mathrm{BC}_{\mathrm{C}}$ purées caused a significant decrease in polyphenols and flavonoids, of approximately $60 \%$ and $52 \%$, respectively. The selected phytochemicals were more stable in $\mathrm{BV}_{\mathrm{C}}$, with a reduction of approximately $21 \%$ and $30 \%$, respectively. However, when drying by infrared technology, polyphenols and flavonoids were found to decrease in $\mathrm{BC}_{\mathrm{IR}}$ by $62 \%$ and $23 \%$, respectively, whereas in $\mathrm{BV}_{\mathrm{IR}}$ a slight decrease in polyphenols (of 19\%) and an increase of $20 \%$ in flavonoids content was observed.

A significant decrease of approximatively $72 \%$ was found in antioxidant activity of $B C_{C}$ purées caused by convective drying, whereas heating by infrared of $\mathrm{BV}_{\mathrm{C}}$ leads to an increase of $70 \% \mathrm{ABTS}$ radical scavenging activity, due probably to the increase in flavonoid content. The hydrolysis of C-glycosides in the flavonoid composition leads to the formation of monomers that increase the total amount of flavonoids, as well as the antioxidant capacity [30].

Guldiken et al. [31] pointed out that during processing, including drying, the phytochemicals in the red beet products undergo both increases and decrease. For example, Sawicki et al. [32] analyzed three types of processing parameters of red beetroot (boiling, fermentation, and microwave-vacuum treatment) and suggested that the main compound among the betacyanins group in the analyzed products was betanin, while the predominant compound from the betaxanthins group was vulgaxanthin I. This phenomenon occurs as a result of red beet exposure to light and temperature, causing the transformation of betacyanins into decarboxylated forms. A significant reduction of total betalains with approximatively $54 \%$ was also observed by these authors when boiling whole roots for $45 \mathrm{~min}$, while the total betacyanin and betaxanthin contents decreased by approximately $43 \%$ and $87 \%$, respectively. Similar results were reported by Sawicki and Wiczkowski [33], suggesting a significant $54 \%$ reduction in the total betalains content after boiling of whole roots for $60 \mathrm{~min}$.

\subsection{Cells Viability}

During the storage time $\left(28\right.$ days at $\left.4{ }^{\circ} \mathrm{C}\right)$, a decrease in the number of L. casei $431^{\circledR}$ viable cells of all samples was observed. Thus, the number of L. casei $431^{\circledR}$ cells decreased after 21 days from $8.79 \log \mathrm{CFU} / \mathrm{g}$ to $7.17 \log \mathrm{CFU} / \mathrm{g}$ for samples $\mathrm{BV}_{\mathrm{C}}$ and $\mathrm{BV}_{\mathrm{IR}}$. For samples $\mathrm{BC}_{\mathrm{C}}$ and $\mathrm{BC}_{\mathrm{IR}}$ in the same conditions, the number of L. casei $431^{\circledR}$ cells decreased from $8.58 \log \mathrm{CFU} / \mathrm{g}$ to $7.89 \log \mathrm{CFU} / \mathrm{g}$. A similar tendency was reported by Paraschiv et al. [34] for a probiotic L. casei $431^{\circledR}$ strain, after 21 days, during the storage in refrigeration conditions. The drying method did not significantly affect the cell viability. However, higher viability by $1 \log \mathrm{CFU} / \mathrm{g}$ was observed in $\mathrm{BC}$ purée samples compared with BV purée samples. 
For a food to be considered probiotic, it must contain viable probiotic cultures in populations over $6 \log$ CFU/g during the shelf life of the product [35]. L. casei $431^{\circledR}$ remained viable in populations of more than $7 \log \mathrm{CFU} / \mathrm{g}$ during 21 days of storage for all samples, which makes the red beet purée suitable to be defined as a functional product.

\subsection{In Vitro Release of Betalains}

The in vitro digestion of purées was determined by simulating the gastric and intestinal phases. The content of the betalains in the digestion phases resulting from in vitro gastrointestinal digestion of red beet products was analyzed. As suggested by Sawicki et al. [32], the obtained results may offer the opportunity to evaluate the changes in the total content of betalains after in vitro digestion and the potential for in vitro bioaccessibility of the main phytochemicals from beetroot dried powders. As shown in Figure 1a, the total betalains content decrease from convection dried red beet powders in $\mathrm{BC}_{\mathrm{C}}$ after in vitro gastric digestion up to $20 \%$ during $120 \mathrm{~min}$ of reaction.

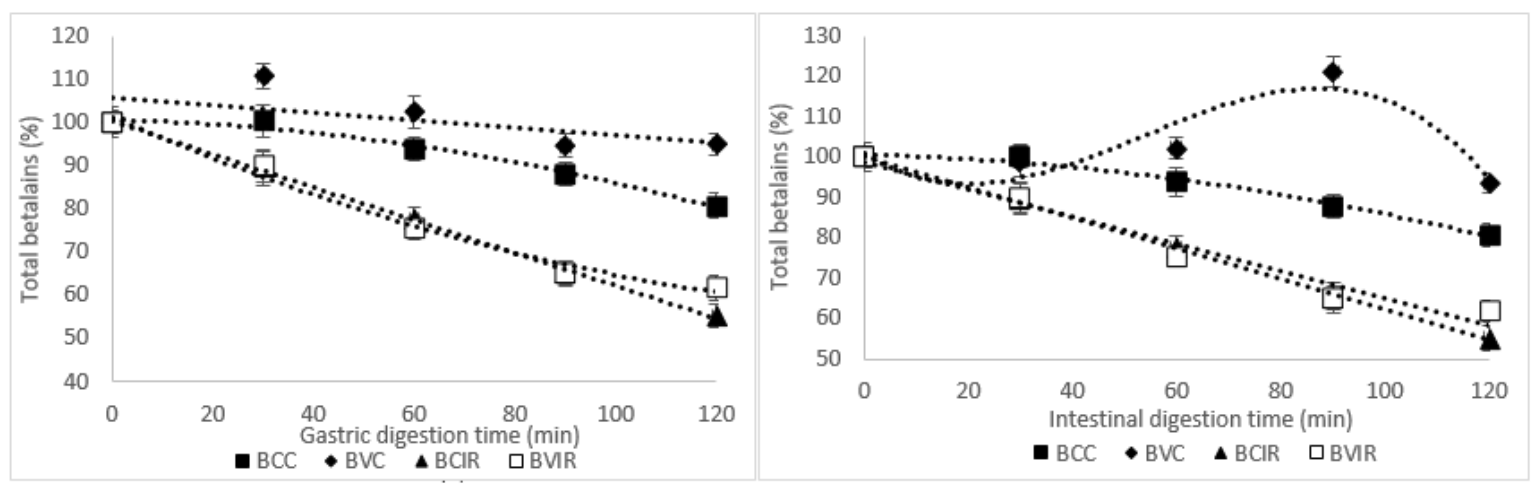

(a)

(b)

Figure 1. The in vitro digestion of total betalains in powders samples in gastric simulated juice (a) and intestinal simulated juice $(\mathbf{b})$ : $\mathrm{BV}_{\mathrm{C}}, \mathrm{BC}_{\mathrm{C}}$-red beet purée dried by convection method; $\mathrm{BV}_{\mathrm{IR}}, \mathrm{BC}_{\mathrm{IR}}$-red beet purée dried by infra-red (IR) method.

The total concentration of betalains from $\mathrm{BV}_{\mathrm{C}}$ in the gastric phases were increased by up to $10 \%$ after $30 \mathrm{~min}$ of digestion and decreased up to a maximum of $5 \%$ after $120 \mathrm{~min}$ (Figure 1a). Significantly, the decrease in total betalains content continued in intestinal simulated juice for $\mathrm{BC}_{C}$, ranging from $6 \%$ at the beginning of digestion to a maximum of $19 \%$ after $120 \mathrm{~min}$ of reaction. In $\mathrm{BV}_{\mathrm{C}}$, a release in the total betalains was observed in the first $90 \mathrm{~min}$ of intestinal digestion, up to $21 \%$, followed by a decrease in total betalains content (Figure 1b).

The infrared dried pattern of the total betalains in in vitro digestion is given in Figure 1a. In gastric digestion, $\mathrm{BC}_{\mathrm{IR}}$ and $\mathrm{BV}_{\mathrm{IR}}$ showed a significant decrease in total betalains, of approximately $45 \%$ and $38 \%$, respectively. In simulated intestinal juice, the decrease reached a maximum value of $23 \%$ and $18 \%$ $\mathrm{BC}_{\mathrm{IR}}$ and $\mathrm{BV}_{\mathrm{IR}}$, respectively, after 120 min of reaction (Figure $1 \mathrm{~b}$ ).

It has been suggested that betacyanins and betaxanthins have broad $\mathrm{pH}$ stability in the range $\mathrm{pH}$ 3.0-7.0 [36]. However, in a very acidic or basic environments, the molecules are involved in molecular cleavage, decarboxylation, and formation of other products [36]. Therefore, the significant decrease of total betalains in the gastric environment is probably due to the high instability at acidic conditions. Based on our results, a protective effect of the matrices may be considered in intestinal simulated juice. Our results are in good agreement with Sawicki et al. [32] and Tesoriere et al. [37], suggesting the importance of the food matrix in affecting the stability of betalains to the acidic $\mathrm{pH}$.

\subsection{Structural and Morphological Properties of the Dried Powders}

The confocal analysis revealed the presence of many vegetal tissue fragments, coming from beetroot. These fragments present parenchymal cells, with dimensions of 104.91-110.84 $\mu \mathrm{m}$ (for BV 
sample) and 44.54-116.28 $\mu \mathrm{m}$ (for BC sample). The cellular content is rich in betalains which have an absorption peak at 536-540 $\mathrm{nm}$ and a wide emission spectrum, between 506-660 $\mathrm{nm}$ [25], and are biologically active compounds responsible for the remarkable antioxidant properties for which red beet is in the top 10 the most valuable vegetables [38].

Debris of vascular tissue (fragments of the tracheal elements of xylem), spirally ornamented, are often found, which is an important source of fiber for consumers (Figure 2, $\mathrm{BC}_{\mathrm{IR}}$ ). In comparison with the fresh purees, the reconstituted samples coming from IR drying possess a higher number of lysed cells, with fragmented cell walls, as a consequence of rapid dehydration, which also affected the cellular constituents (Figure 2, $\mathrm{BV}_{\mathrm{IR}}$ and $\mathrm{BC}_{\mathrm{IR}}$ ).

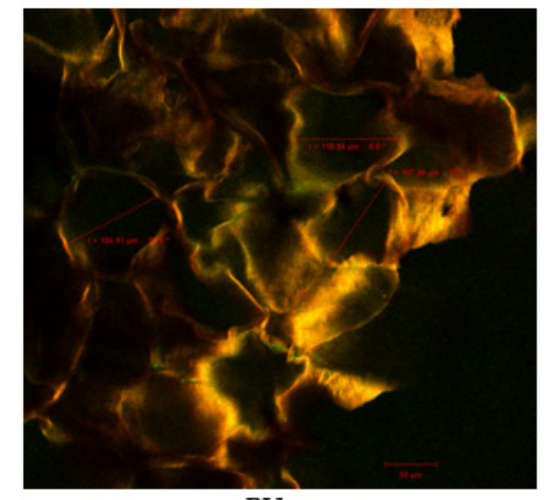

BVo

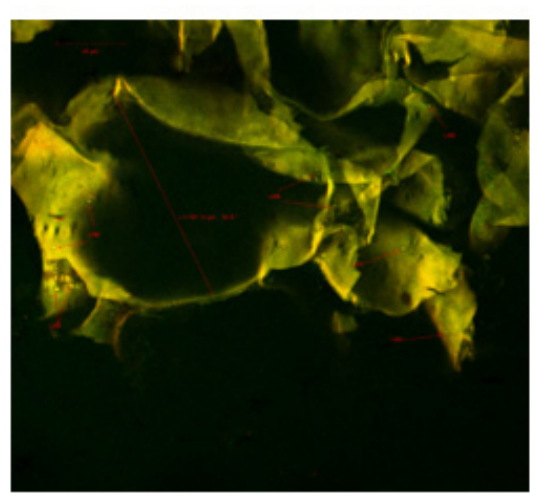

BVc

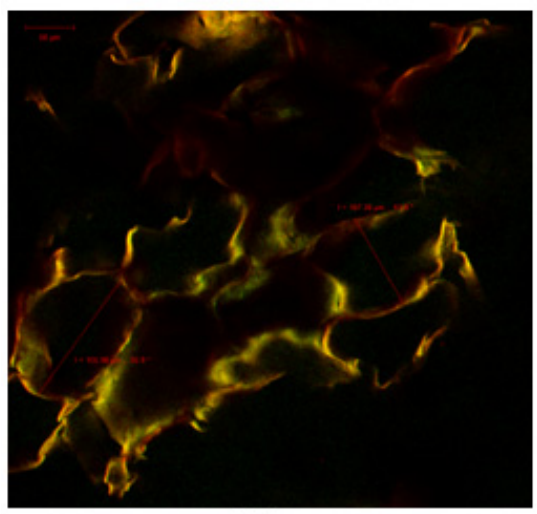

BVIR

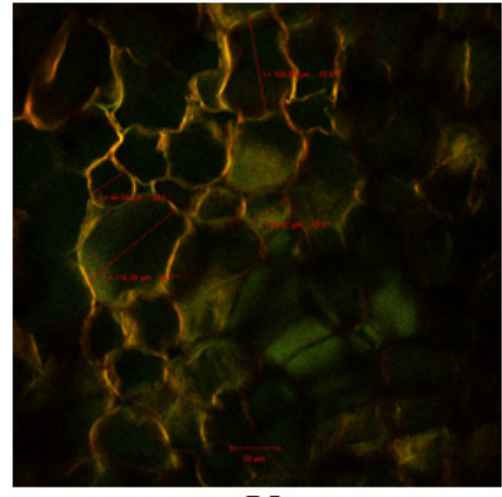

BCo

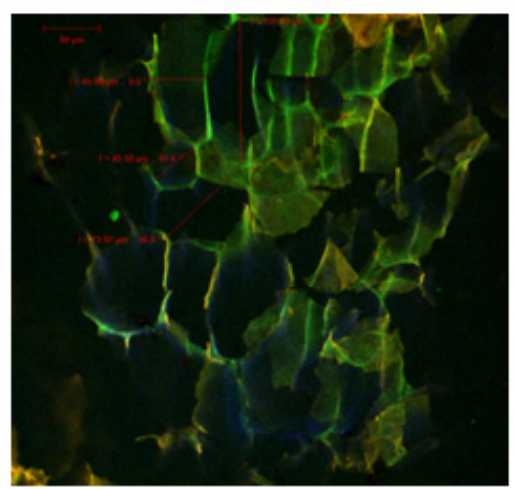

$\mathrm{BCC}$

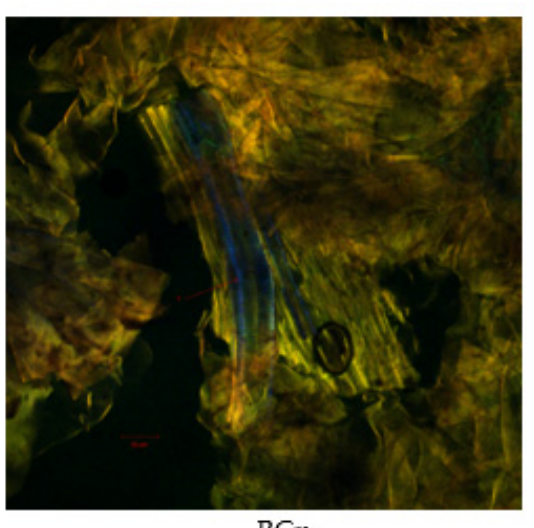

BCIR

Figure 2. Confocal laser microscopy images of fresh and reconstituted red beetroot purée samples obtained with objective lenses of $20 \mathrm{x}: \mathrm{BV}_{0}$-fresh sample of Beta vulgaris $\mathrm{L}$. var. vulgaris; $\mathrm{BC}_{0}$-fresh sample of Beta vulgaris L. var. cylindra; $\mathrm{BV}_{\mathrm{C}}, \mathrm{BC}_{\mathrm{C}}$-red beet purée dried by convection method; $\mathrm{BV}_{\mathrm{IR}}$, $\mathrm{BC}_{\mathrm{IR}}$-red beet purée dried by infra-red (IR) method; scale bar $50 \mu \mathrm{m}$. 
The convection drying technology is milder, a fact proved by the confocal images captured from the reconstituted $\mathrm{BV}_{\mathrm{C}}$ and $\mathrm{BC}_{\mathrm{C}}$ samples in which large cells can be visualized after rehydration $(187.12 \mu \mathrm{m}$, respectively $137.33 \mu \mathrm{m})$, with rich content in valuable vegetable pigments (in green-yellow). In the $\mathrm{BV}_{\mathrm{C}}$ samples, acquired with ZEN 2012 SP1 Black software, zoom 1.2, it can be seen even the microcolonies/biofilms resulting from the aggregation of probiotic lactic acid bacteria (L. casei 431 strain) from the functional product. Carbohydrates and biologically active compounds from plant tissue are an excellent support for maintaining the viability of lactic acid bacteria, so they will act synergistically and symbiotically. This result is also supported by previous studies by Barbu et al. [39] who used a strain of $\mathrm{Lb}$. plantarum BL3 to obtain three variants of functional products based on beetroot.

\subsection{FTIR}

The FTIR spectra of all the red beetroot tested samples were recorded in the spectral range of $400-4000 \mathrm{~cm}^{-1}$ are shown in Figure 3. As can be seen, the main differences between the FTIR spectra of convection and IR dried beetroot samples were observed in the spectral ranges of 1028-1039. The FTIR spectra recorded weak to wide bands at 3550 and $1623 \mathrm{~cm}^{-1}$, which correspond to stretching vibrations of $\mathrm{OH}$ groups and $\mathrm{H}-\mathrm{O}-\mathrm{H}$ bending arising from the moisture content of the red beetroot test samples, respectively. The weak bands were due to the loss of moisture content generated by the drying process. Similar findings were reported by Nesakumar et al. [40] in a study over the spoilage of red beetroot and by Singh et al. [41] for the extraction of betalain pigments from beta Vulgaris peels by microwave pretreatment.

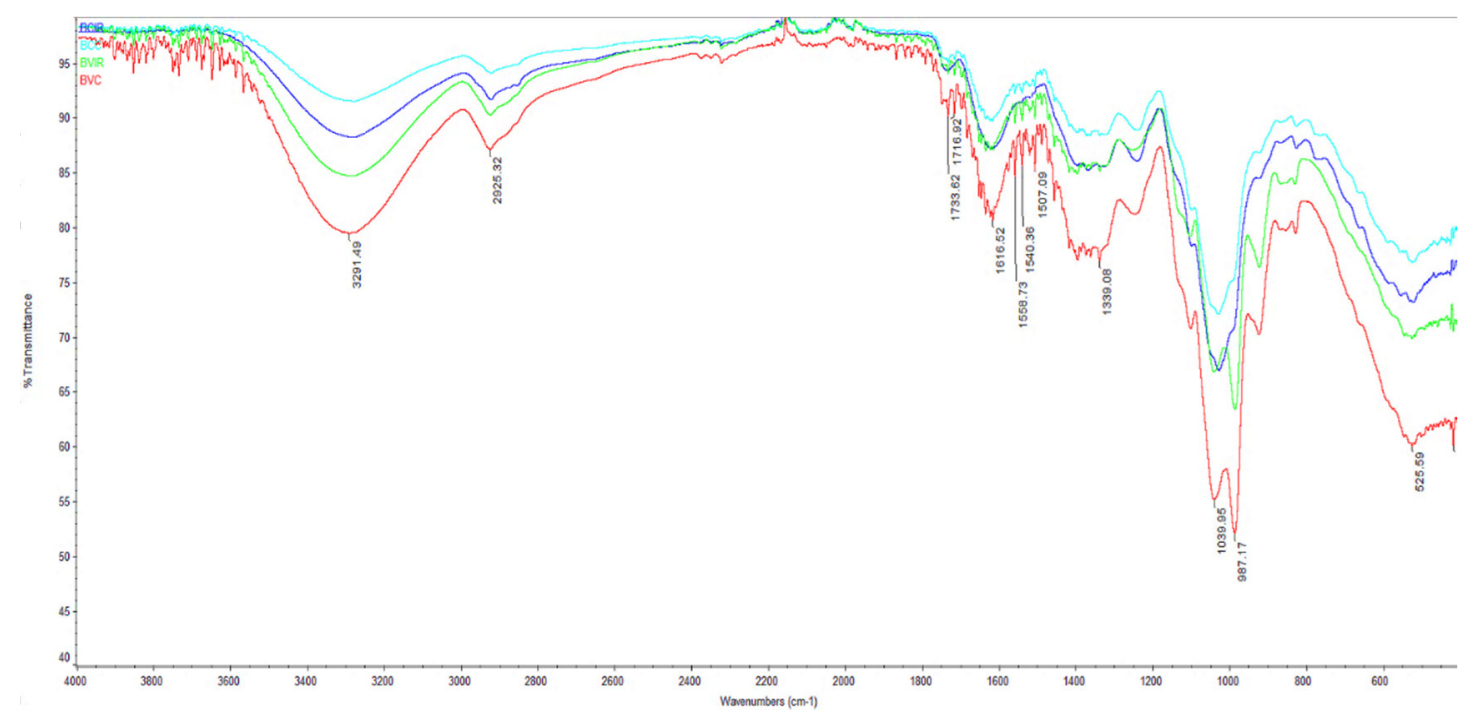

Figure 3. Fourier-transform infrared spectroscopy spectra of red beetroot dried samples: $B V_{C}, B C_{C}-$ red beet purée dried by convection method; $\mathrm{BV}_{\mathrm{IR}}, \mathrm{BC}_{\mathrm{IR}}$-red beet purée dried by infra-red (IR) method.

\subsection{Color Parameters}

According to Henao-Ardila et al. [42] for acceptability of a powdered product, color represents an important parameter considered essential by the consumers, so reconstituted powder should have the same color as the fresh product. A significant effect on the color changes of the red beet is to be found in the processing temperatures and drying methods. The results of the color measurement for fresh and dried red beet purées are shown in Table 2. 
Table 2. Effects of drying treatment on color parameters of fresh and dried red beetroot purées.

\begin{tabular}{|c|c|c|c|c|c|c|}
\hline \multirow{2}{*}{ Color Parameters } & \multicolumn{2}{|c|}{ Fresh Samples } & \multicolumn{4}{|c|}{ Dried Samples } \\
\hline & $\mathbf{B V}_{0}$ & $\mathrm{BC}_{0}$ & $\mathbf{B V}_{\mathbf{C}}$ & $\mathrm{BV}_{\mathrm{IR}}$ & $\mathrm{BC}_{\mathrm{C}}$ & $\mathrm{BC}_{\mathrm{IR}}$ \\
\hline$L^{*}$ & $21.16 \pm 0.3^{B}$ & $21.19 \pm 0.15^{\text {B }}$ & $25.78 \pm 0.15^{\text {B }}$ & $30.67 \pm 0.02^{\mathrm{B}}$ & $29.68 \pm 0.12^{B}$ & $32.15 \pm 0.12^{B}$ \\
\hline$a^{*}$ & $5.00 \pm 0.2^{B, C}$ & $8.32 \pm 0.03^{B, C}$ & $10.29 \pm 0.22^{B, C}$ & $14.19 \pm 0.02^{\mathrm{B}, \mathrm{C}}$ & $25.66 \pm 0.26^{\mathrm{B}, \mathrm{C}}$ & $29.14 \pm 0.04^{B, C}$ \\
\hline$b^{*}$ & $1.45 \pm 0.04^{C}$ & $1.41 \pm 0.02 \mathrm{C}$ & $5.07 \pm 0.21 \mathrm{C}$ & $6.56 \pm 0.12^{C}$ & $6.02 \pm 0.03^{C}$ & $7.78 \pm 0.04^{C}$ \\
\hline$\Delta E$ & - & - & $8.02 \pm 0.27^{B, C}$ & $14.84 \pm 0.28^{B, C}$ & $19.84 \pm 0.28^{\mathrm{B}, \mathrm{C}}$ & $24.37 \pm 0.21^{B, C}$ \\
\hline$C^{*}$ & $5.21 \pm 0.20^{\mathrm{B}, \mathrm{C}}$ & $8.44 \pm 0.03^{B, C}$ & $11.47 \pm 0.24^{\mathrm{B}, \mathrm{C}}$ & $15.64 \pm 0.03^{B, C}$ & $26.35 \pm 0.04^{B, C}$ & $30.16 \pm 0.25^{\mathrm{B}, \mathrm{C}}$ \\
\hline$h^{*}$ & $16.17 \pm 0.31^{\mathrm{B}, \mathrm{C}}$ & $9.62 \pm 0.11^{B, C}$ & $26.23 \pm 0.18^{B, C}$ & $24.81 \pm 0.47^{\mathrm{B}, \mathrm{C}}$ & $13.20 \pm 0.06^{\mathrm{B}, \mathrm{C}}$ & $14.95 \pm 0.10^{\mathrm{B}, \mathrm{C}}$ \\
\hline$B I$ & $28.57 \pm 0.00^{\mathrm{A}}$ & $35.29 \pm 0.00 \mathrm{~A}$ & $47.05 \pm 0.00^{\mathrm{A}}$ & $52.94 \pm 0.00 \mathrm{~A}$ & $76.47 \pm 0.00 \mathrm{~A}$ & $88.23 \pm 0.00^{\mathrm{A}}$ \\
\hline WI & $20.98 \pm 0.29^{\mathrm{B}, \mathrm{C}}$ & $20.74 \pm 0.15^{\text {B,C }}$ & $24.89 \pm 0.11^{\mathrm{B}, \mathrm{C}}$ & $28.93 \pm 0.03^{\mathrm{B}, \mathrm{C}}$ & $24.90 \pm 0.11^{B, C}$ & $25.75 \pm 0.04^{\mathrm{B}, \mathrm{C}}$ \\
\hline$Y I$ & $9.78 \pm 0.28^{B, C}$ & $9.51 \pm 0.09 \mathrm{~B}, \mathrm{C}$ & $28.09 \pm 0.28^{B, C}$ & $30.56 \pm 0.60^{B, C}$ & $28.97 \pm 0.13^{B, C}$ & $34.57 \pm 0.22^{\mathrm{B}, \mathrm{C}}$ \\
\hline
\end{tabular}

$\mathrm{BV}_{0}$-fresh sample of Beta vulgaris L. var. vulgaris; $\mathrm{BC}_{0}$-fresh sample of Beta vulgaris $\mathrm{L}$. var. cylindra; $\mathrm{BV}_{\mathrm{C}}, \mathrm{BC}_{\mathrm{C}}-\mathrm{red}$ beet purée dried by convection method; $\mathrm{BV}_{\mathrm{IR}}, \mathrm{BC}_{\mathrm{IR}}$-red beet purée dried by IR method. Means that do not share a letter as a superscript $(\mathrm{A}, \mathrm{B}, \mathrm{C})$ are significantly different. $L^{*}$ - clarity; $a^{*}$-red/green colour component; $b^{*}$-blue/yellow colour component; $\Delta E$ —-total colour difference; $C^{*}$ — chroma; $h^{*}$ —hue angle; $B I$ —browning index; WI-whiteness index; YI-yellowness index.

The color values (for each type of drying method and plant material) were registered and indicated that the $L^{*}, a^{*}$, and $b^{*}$ parameters increased for all powder samples as compared to the fresh samples. $L^{*}$ values, which show the whiteness of the product, ranged between $21.16 \pm 0.21$ and $30.67 \pm 0.02$ for samples obtained from BV and between $21.19 \pm 0.15$ and $32.15 \pm 0.12$ for samples obtained from BC. After drying, the color of powder samples became lighter and reddish probably due to the betacyanins. $\mathrm{Ng}$ and Sulaiman [43] observed similar results for beetroot powder while Ochoa-Martinez et al. [44] for beetroot-orange juice. They also reported that thermal processing causes some modifications in red-orange betanins, by increasing the values of the red/green color parameter $\left(a^{*}\right)$. The color coordinate $\left(a^{*}\right)$ varied between $5.00 \pm 0.21\left(\mathrm{BV}_{0}\right)$ and $29.14 \pm 0.04\left(\mathrm{BC}_{\mathrm{IR}}\right)$. In the case of dried samples, a maximum change of color was about $51.72 \%$ and this percent was established for the sample $\mathrm{BC}_{\mathrm{IR}}$ compared with the value of the fresh product. The IR drying process may induce rapid heat penetration directly into the product. Therefore, a higher color change in IR dried samples compared with convective dried samples was noticed. $b^{*}$ values of dried red beetroot samples increased compared with the values of the fresh samples. The increase of the $b^{*}$ value was reflected by the decomposition of betanin with the occurrence of yellow compounds as betalamic acid, or condensation of betalamic acid with amino compounds (betaxanthins) or cyclo-DOPA (neobetacianins) [45].

The $C^{*}$ values of the fresh red beetroot purée increase after the convection and IR drying process. In general, the $C^{*}$ value ranged from $5.21 \pm 0.20$ to $30.16 \pm 0.25$. When the value of the hue angle $\left(h^{*}\right)$ presented in Table 2 was checked, it can be concluded that this value tended to grow for all dried samples in the same mode as for the chroma $\left(C^{*}\right)$ values. The visual color appearance value $\left(h^{*}\right)$ in beetroot powders was the highest in the samples processed by convection method $(26.23 \pm 0.18$ for $\mathrm{BV}_{\mathrm{C}}$ sample), followed by the fresh sample and the other IR treated samples. The appearance of the product, i.e., the color, is very important for the consumers; for that reason, $\Delta E$ represents an important color parameter of the dried product, which reveals the human eye's capacity to differentiate the colors of the samples. The total color change $(\Delta E)$ of the dried red beetroot samples varied from $8.02 \pm 0.27$ to $24.37 \pm 0.21$ units, influenced by the applied drying method and temperature. The $L^{*}, a^{*}$, and $b^{*}$ parameters were used to appreciate browning index $(B I)$, which indicates the purity of the brown color, whiteness index $(W I)$, which is an indicator of enzymatic discoloration and yellowness index $(Y I)$. $Y I$ is associated with product degradation by light, chemical exposure, and processing. Regarding the $\mathrm{BI}$, the fresh red beetroot purées showed the lowest values $\left(28.57 \pm 0.00\right.$ for $\mathrm{BV}_{0}$ and $35.29 \pm 0.00$ for $\left.\mathrm{BC}_{0}\right)$. In our study, the values of $\mathrm{BI}$ increased, due to the enzymatic and non-enzymatic reactions that took place at a low temperature-short period of time. The increased YI values for all dried samples compared to the fresh samples can be assigned to the pigment decomposition and the occurrence of Maillard reactions. 


\subsection{Textural and Oscillatory Measurements}

\subsubsection{Texture Analysis}

The texture analysis of the purée samples (Table 3) revealed that IR drying induced fewer damages in the vegetal tissue, comparing with convection drying. This could be concluded from the values of firmness, which are the lowest in the case of fresh pureés $\left(0.76 \pm 0.03 \mathrm{~N}\right.$ for $\mathrm{BV}_{0}$ and $0.72 \pm 0.05 \mathrm{~N}$ for $\left.\mathrm{BC}_{0}\right)$. The rehydrated samples did not manage to absorb the same amount of water which was removed during the drying process. Therefore, the vegetal particles are firmer and tend to gather at the bottom of the container, leading to increased firmness. At the same time, at rehydration, the purée particles did not manage to recover the bonds between them, due to cell war disruptions and fissures as reported by several microstructure studies [12,30]. This fact leads to lower adhesiveness, springiness, and cohesiveness values in the rehydrated samples.

Table 3. The values of textural parameters.

\begin{tabular}{lcccccc}
\hline \multicolumn{1}{c}{ Parameter } & $\mathbf{B V}_{\mathbf{0}}$ & $\mathbf{B V}_{\mathbf{C}}$ & $\mathbf{B V}_{\mathbf{I R}}$ & $\mathbf{B C}_{\mathbf{0}}$ & $\mathbf{B C}_{\mathbf{C}}$ & $\mathbf{B C}_{\mathbf{I R}}$ \\
\hline Firmness, N & $0.76 \pm 0.03^{\mathrm{B}}$ & $1.31 \pm 0.15^{\mathrm{B}}$ & $0.97 \pm 0.04^{\mathrm{B}}$ & $0.72 \pm 0.05^{\mathrm{B}}$ & $1.26 \pm 0.01^{\mathrm{B}}$ & $1.02 \pm 0.04^{\mathrm{B}}$ \\
Adhesiveness, mJ & $3.38 \pm 0.29^{\mathrm{B}}$ & $0.69 \pm 0.02^{\mathrm{B}}$ & $0.35 \pm 0.01^{\mathrm{B}}$ & $4.58 \pm 0.31^{\mathrm{B}}$ & $0.44 \pm 0.02^{\mathrm{B}}$ & $0.25 \pm 0.02^{\mathrm{B}}$ \\
Cohesiveness, - & $0.72 \pm 0.10^{\mathrm{B}}$ & $0.47 \pm 0.01^{\mathrm{B}}$ & $0.46 \pm 0.09^{\mathrm{B}}$ & $0.67 \pm 0.02^{\mathrm{B}}$ & $0.45 \pm 0.01^{\mathrm{B}}$ & $0.42 \pm 0.01^{\mathrm{B}}$ \\
Springiness, mm & $9.18 \pm 0.19^{\mathrm{A}}$ & $5.77 \pm 0.07^{\mathrm{A}}$ & $6.23 \pm 0.10^{\mathrm{A}}$ & $8.72 \pm 0.10^{\mathrm{A}}$ & $5.29 \pm 0.08^{\mathrm{A}}$ & $6.06^{2} \pm 0.07^{\mathrm{A}}$ \\
\hline
\end{tabular}

$\mathrm{BV}_{0}$-fresh sample of Beta vulgaris L. var. vulgaris; $\mathrm{BC}_{0}$-fresh sample of Beta vulgaris $\mathrm{L}$. var. cylindra; $\mathrm{BV}_{\mathrm{C}}, \mathrm{BC}_{\mathrm{C}}-\mathrm{red}$ beet purée dried by convection method; $\mathrm{BV}_{\mathrm{IR}}, \mathrm{BC}_{\mathrm{IR}}$-red beet purée dried by infra-red (IR) method. Means that do not share a letter as a superscript (A, B, C) are significantly different.

When comparing the values of the textural parameters obtained for convectional drying with those obtained for IR drying, it can be noticed that the latter are closer to fresh samples. It can be concluded that IR drying is milder compared to the convectional one. As for beetroot varieties, from a textural point of view, no major differences between samples were observed.

\subsubsection{Rheological Analysis Results}

The rheological behavior of the fresh and reconstituted beetroot purée samples is presented in Figures 4 and 5. For both of the beetroot varieties purées, the fresh samples registered lower resistance to the applied stress when compared to the reconstituted samples. This behavior could be explained by the insoluble particles presented in the rehydrated samples, which lead to a more rigid network than in the fresh purée, as observed by Leverrier et al. [46] for apple purée.

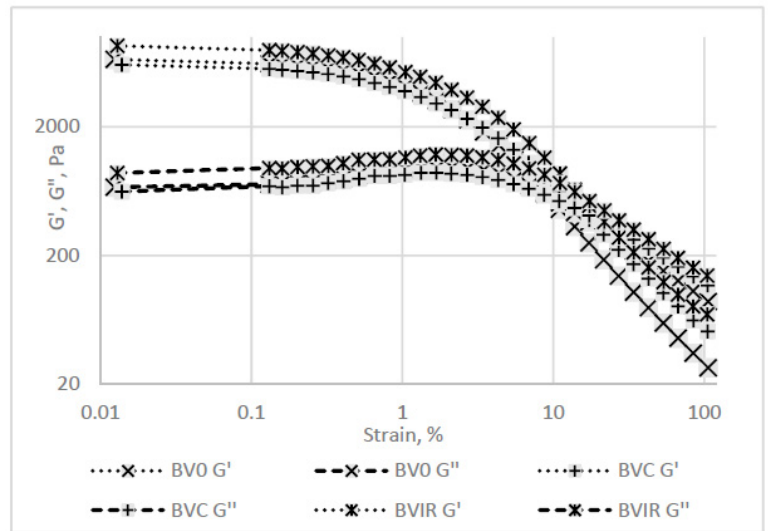

(a)

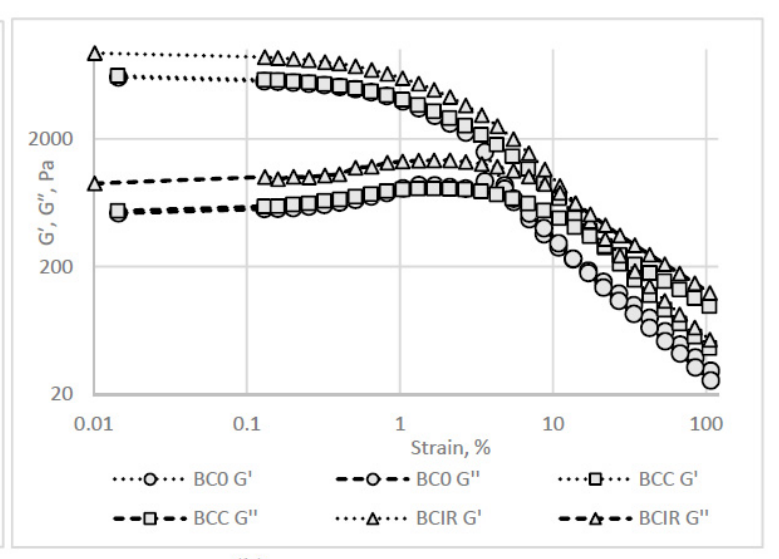

(b)

Figure 4. Rheological behavior as revealed by the strain sweep test: (a) Beta vulgaris L. var. vulgaris, (b) Beta vulgaris L. var. cylindra. 


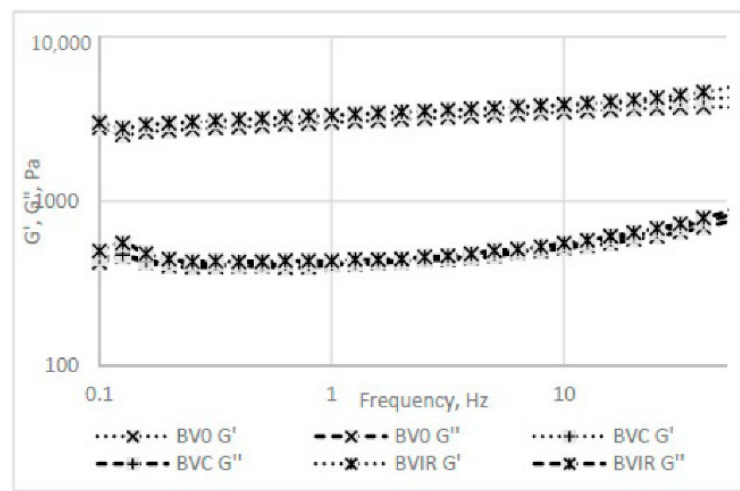

(a)

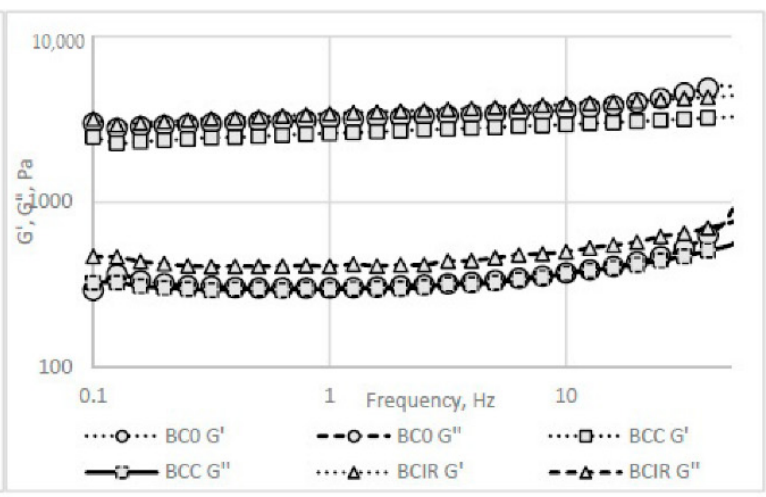

(b)

Figure 5. Rheological behavior as revealed by the frequency sweep test: (a) Beta vulgaris L. var. vulgaris, (b) Beta vulgaris L. var. cylindra.

The frequency sweep test revealed a gel-like behavior for all purée samples, as the elastic modulus $\left(G^{\prime}\right)$ shows higher values than the loss modulus $\left(G^{\prime \prime}\right)$.

The IR drying determined a reconstituted purée sample that presented the highest consistency, stiffness, and resistance to flow marked by the $G^{\prime} / G^{\prime \prime}$ intersection point, usually associated with the structure breakdown and beginning of the flow.

\section{Conclusions}

Two varieties of red beetroot were studied as potential sources of betalains, polyphenols, and flavonoids in fresh and dried forms of purées, from the perspectives of developing foods or food-grade ingredients with functional values, in terms of phytochemical and lactic acid bacteria. The drying of red beetroot influenced the phytochemical profile of both varieties, with a more protective effect registered for infrared drying processing. However, when drying by infrared technology, polyphenols and flavonoids were found to decrease in Beta vulgaris L. var. cylindra, whereas in Beta vulgaris L. var. vulgaris, a slight decrease in polyphenols and an increase in flavonoids content was observed. The decrease in phytochemicals significantly affected the antioxidant activity of the purées, regardless of the drying technology. In all the dried powders, a one logarithmic decrease in lactic acid bacteria viability was registered. After drying, the color of beetroot powder samples became lighter and reddish.

Our study brings some valuable results involving the optimization of drying processes to validate the quality of phytochemicals retention. The high antioxidant activity of red beet powders combined with a $10^{7} \mathrm{CFU} / \mathrm{g}$ for lactic acid bacteria represents a good base for the development of a biosynthetic process to obtain additives with a potential for application in the food and pharmaceutical industry.

Author Contributions: Conceptualization, N.S. and G.-D.M.; formal analysis, A.C.C., A.M.V., D.G.A., O.-V.N., and V.B.; writing—original draft preparation, N.S., G.-D.M., A.M.V., D.G.A., O.-V.N., and V.B.; writing一review and editing, N.S. All authors have read and agreed to the published version of the manuscript.

Funding: This research received no external funding.

Acknowledgments: This work was supported by the project "Excellence, performance and competitiveness in the Research, Development and Innovation activities at "Dunarea de Jos" University of Galati", acronym "EXPERT", financed by the Romanian Ministry of Research and Innovation in the framework of Programme 1-Development of the national research and development system, Sub-programme 1.2-Institutional Performance-Projects for financing excellence in Research, Development and Innovation, Contract no. 14PFE/17.10.2018. The authors are grateful for the technical support offered by the Grant POSCCE ID 1815, cod SMIS 48745 (www.moras.ugal.ro). The Integrated Center for Research, Expertise and Technological Transfer in Food Industry is acknowledged for providing technical support.

Conflicts of Interest: The authors declare no conflict of interest. 


\section{References}

1. Angelino, D.; Godos, J.; Ghelfi, F.; Tieri, M.; Titta, L.; Lafranconi, A.; Marventano, S.; Alonzo, E.; Gambera, A.; Sciacca, S.; et al. Fruit and vegetable consumption and health outcomes: An umbrella review of observational studies. Int. J. Food Sci. Nutr. 2019, 70, 652-667. [CrossRef]

2. Rocchetti, G.; Tomas, M.; Zhang, L.; Zengin, G.; Lucini, L.; Capanoglu, E. Red beet (Beta vulgaris) and amaranth (Amaranthus sp.) microgreens: Effect of storage and in vitro gastrointestinal digestion on the untargeted metabolomic profile. Food Chem. 2020, 332, 127415. [CrossRef] [PubMed]

3. Stintzing, F.C.; Carle, R. Functional properties of anthocyanins and betalains in plants, food and in human nutrition. Trends Food Sci. Technol. 2004, 15, 19-38. [CrossRef]

4. Strack, D.; Vogt, T.; Schliemann, W. Recent advances in betalain research. Phytochemistry 2003, 62, $247-269$. [CrossRef]

5. Reddy, K.M.; Ruby, L.; Lindo, A.; Nair, G.M. Relative inhibition of lipid peroxidation, cyclooxygenase enzymes and human tumor cells prolifieration by natural food color. J. Agric. Food Chem. 2005, 53, 9268-9273. [CrossRef]

6. Delgado-Vargas, F.; Jiménez, A.R.; Paredes-López, O. Natural pigments: Carotenoids, anthocyanins, and betalains-characteristics, biosynthesis, processing, and stability. Crit. Rev. Food Sci. Nutr. 2000, 40, 173-289. [CrossRef] [PubMed]

7. Gentile, C.; Tesoriere, L.; Allegra, M.; Livrea, M.A.; Alessio, P.D. Antioxidant betalains from cactus pear (Opuntia ficus-indica) inhibit endothelial ICAM-1expression. Ann. N. Y. Acad. Sci. 2004, 1028, 481-486. [CrossRef]

8. Tesoriere, L.; Allegra, M.; Butera, D.; Livrea, M.A. Absorption, excretion, and distribution of dietary antioxidant betalains in LDLs Potential health effects of betalains in humans. Am. J. Clin. Nutr. 2004, 80, 941-945. [CrossRef]

9. Różyło, R. Recenttrends in methods used to obtain natural food colorants by freeze-dryin. Trends Food Sci. Technol. 2020, 102, 39-50. [CrossRef]

10. Azeredo, H.M.C. Betalains: Properties, sources, applications, and stability: A review. Int. J. Food Sci. Tech. 2009, 44, 2365-2376. [CrossRef]

11. Dandamrongrak, R.; Young, G.; Mason, R. Evaluation of various pre-treatments for the dehydration of banana and selection of suitable drying models. J. Food Eng. 2002, 55, 136-146. [CrossRef]

12. Vallespir, F.; Rodríguez, O.; Eim, V.S.; Rosselló, C.; Simal, S. Effects of freezing treatments before convective drying on quality parameters: Vegetables with different microstructures. J. Food Eng. 2019, 249, 15-24. [CrossRef]

13. Kaleta, A.; Górnicki, K. Some remarks on evaluation of drying models of red beet particles. Energy Convers. Manag. 2010, 51, 2967-2978. [CrossRef]

14. Torki-Harchegani, M.; Ghanbarian, D.; Maghsoodi, V.; Moheb, A. Infrared thin layer drying of saffron (Crocus sativus L.) stigmas: Mass transfer parameters and quality assessment. Chin. J. Chem. Eng. 2017, 25, 426-432. [CrossRef]

15. Kipcak, A.S.; Doymaz, İ.; Derun, E.M. Infrared drying kinetics of blue mussels and physical properties. Chem. Ind. Chem. Eng. Q. 2019, 25, 1-10. [CrossRef]

16. Jafari, F.; Movagharnejad, K.; Sadeghi, E. Infrared drying effects on the quality of eggplant slices and process optimization using response surface methodology. Food Chem. 2020, 333, 127423. [CrossRef]

17. Begot, C.; Desnier, I.; Daudin, J.D.; Labadie, J.C.; Lebert, A. Recommendations for calculating growth parameters by optical density measurements. J. Microbiol. Methods 1996, 25, 225-232. [CrossRef]

18. Wehr, H.M.; Frank, J.F. Standard Methods for the Examination of Dairy Products, 17th ed.; APHA Press-American Public Health Association: Washington, DC, USA, 2004.

19. Ravichandran, K.; Saw, N.M.M.T.; Mohdaly, A.A.A.; Gabr, A.M.M.; Kastell, A.; Riedel, H.; Cai, Z.; Knorr, D.; Smetanska, I. Impact of processing of red beet on betalain content and antioxidant activity. Food Res. Int. 2013, 50, 670-675. [CrossRef]

20. Miller, N.J.; Rice-Evans, C.A. Factors influencing the antioxidant activity determined by the ABTS ${ }^{+}$radical cation assay. Free Radic. Res. 1997, 26, 195-199. [CrossRef] 
21. Oancea, A.-M.; Mahadi, H.; Vasile, A.M.; Barbu, V.; Enachi, E.; Bahrim, G.E.; Râpeanu, G.; Silvi, S.; Stănciuc, N. Functional evaluation of microencapsulated anthocyanins from sour cherries skins extract in whey proteins isolate. LWT 2018, 95, 129-135. [CrossRef]

22. [CIE LEAD, EN ISO/CIE 11664-4:2019] Colorimetry_Part 4: CIE 1976 L * $a * b *$ Colour Space; ISO/CIE 11664-4:2019; ISO Copyright Office: Geneva, Switzerland, 2019.

23. Bolin, H.R.; Huxsoll, C.C. Control of minimally processed carrot (Daucus carota) surface discoloration caused by abrasion peeling. J. Food Sci. 1991, 46, 416-418. [CrossRef]

24. Maskan, M. Kinetics of colour change of kiwifruits during hot air and microwave drying. J. Food Eng. 2001, 48, 169-175. [CrossRef]

25. Miguel, M.C. Betalains in Some Species of the Amaranthaceae Family: A Review. Antioxidants 2018, 7, 53. [CrossRef]

26. Wiczkowski, W.; Topolska, J.; Honke, J. Anthocyanins profile and antioxidant capacity of red cabbages are influenced by genotype and vegetation period. J. Funct. Foods 2014, 7, 201-211. [CrossRef]

27. Sawicki, T.; Baczek, N.; Wiczkowski, W. Betalain profile, content and antioxidant capacity of red beetroot dependent on the genotype and root part. J. Funct. Foods 2016, 27, 249-261. [CrossRef]

28. Ninfali, P.; Bacchiocca, M.; Antinelli, A.; Biagiotti, E.; Di Gioacchino, A.M.; Piccoli, G.; Stocchi, V.; Brandi, G. Characterization and biological activity of the main flavonoids from Swiss chard (Beta vulgaris subspecies cycla). Phytomed. Int. J. Phytother. Phytopharm. 2007, 14, 216-221. [CrossRef] [PubMed]

29. Slatnar, A.; Stampar, F.; Vebaric, R.; Jakopic, J. HPLC-MSn identification of betalains profile of different beetroot (Beta vulgaris L. ssp. vulgaris) parts and cultivars. J. Food Sci. 2015, 80, 1952-1958. [CrossRef]

30. Seremet, L.; Nistor, O.V.; Andronoiu, D.G.; Mocanu, G.D.; Barbu, V.V.; Maidan, A.; Rudi, L.; Botez, E. Development of several hybrid drying methods used to obtain red beetroot powder. Food Chem. 2020, 310, 125637. [CrossRef] [PubMed]

31. Guldiken, B.; Toydemir, T.; Memis, K.N.; Okur, S.; Boyacioglu, D.; Capanoglu, E. Home-processed red beetroot (Beta vulgaris L.) products: Changes in antioxidant properties and bioaccessibility. Int. J. Mol. Sci. 2016, 17, 858. [CrossRef]

32. Sawicki, T.; Martinez-Villaluenga, C.; Frias, J.; Wiczkowski, W.; Peñas, E.; Baczek, N.; Zieliñski, H. The effect of processing and in vitro digestion on the betalain profile and ACE inhibition activity of red beetroot products. J. Funct. Foods 2019, 55, 229-237. [CrossRef]

33. Sawicki, T.; Wiczkowski, W. The effects of boiling and fermentation on betalain profiles and antioxidant capacities of red beetroot products. Food Chem. 2018, 259, 292-303. [CrossRef]

34. Paraschiv, D.; Vasile, A.; Constantin, M.; Ciobanu, A.; Bahrim, G. Study of physiological properties of some probiotics in multiple cultures with mesophilic lactic acid bacteria by Flora Danica $\mathrm{Ch}$. Hansen commercial starter. Ann. Univ. Dunarea Jos Galati Fasc. VI Food Technol. 2011, 35, 56-65.

35. Trisnawita, Y.; Silalahi, J.; Sinaga, S.M. The effect of storage condition on viability of lactic acid bacteria in probiotic product. Asian J. Pharm. Clin. Res. 2018, 11, 84-86. [CrossRef]

36. Herbach, K.M.; Stintzing, F.C.; Carle, R. Betalain stability and degradation. Structural and chromatic aspects. J. Food Sci. 2006, 71, R41-R50. [CrossRef]

37. Tesoriere, L.; Fazzari, M.; Angileri, F.; Gentile, C.; Livrea, M.A. In Vitro Digestion of Betalainic Foods. Stability and Bioaccessibility of Betaxanthins and Betacyanins and Antioxidative Potential of Food Digesta. J. Agric. Food Chem. 2008, 56, 10487-10492. [CrossRef] [PubMed]

38. Vinson, J.A.; Hao, Y.; Su, X.; Zubik, L. Phenol antioxidant quantity and quality in foods: Vegetables. J. Agric. Food Chem. 1998, 46, 3630-3634. [CrossRef]

39. Barbu, V.; Cotârlet, M.; Bolea, C.A.; Cantaragiu, A.; Andronoiu, D.G.; Bahrim, G.E.; Enachi, E. Three Types of Beetroot Products Enriched with Lactic Acid Bacteria. Foods 2020, 9, 786. [CrossRef]

40. Nesakumar, N.; Baskar, C.; Kesavan, S.; Rayappan, J.B.B.; Alwarappan, S. Analysis of Moisture Content in Beetroot using Fourier Transform Infrared Spectroscopy and by Principal Component Analysis. Sci. Rep. 2018, 8, 1-10. [CrossRef] [PubMed]

41. Singh, A.; Ganesapillai, M.; Gnanasundaram, N. Optimizaton of extraction of betalain pigments from beta vulgaris peels by microwave pretreatment. Mater. Sci. Eng. 2017, 263, 1-10. [CrossRef]

42. Henao-Ardila, A.; Quintanilla-Carvajal, M.X.; Moreno, F.L. Combination of freeze concentration and spray drying for the production of feijoa (Acca sellowiana b.) pulp powder. Powder Technol. 2019, 344, 190-198. [CrossRef] 
43. Ng, M.L.; Sulaiman, R. Development of beetroot (Beta vulgaris) powder using foam mat drying. LWT 2018, 88, 80-86. [CrossRef]

44. Ochoa-Martinez, L.A.; Garza-Juarez, S.E.; Rocha-Guzman, N.E.; Morales-Castro, J.; Gonzalez-Herrera, S.M. Functional Properties, Color and Betalain Content in Beetroot-Orange Juice Powder Obtained by Spray Drying. Res. Rev. J. Food Dairy Technol. 2015, 3, 30-36.

45. Antigo, J.L.D.; Bergamasco, R.; Scaramal Madrona, G. Effect of ph on the stability of red beet extract (Beta vulgaris L.) microcapsules produced by spray drying or freeze drying. Food Sci. Technol. Camp. 2018, 38, 72-77. [CrossRef]

46. Leverrier, C.; Almeida, G.; Espinosa-Munoz, L.; Cuvelier, G. Influence of Particle Size and Concentration on Rheological Behaviour of Reconstituted Apple Purees. Food Biophys. 2016, 11, 235-247. [CrossRef]

Publisher's Note: MDPI stays neutral with regard to jurisdictional claims in published maps and institutional affiliations.

(C) 2020 by the authors. Licensee MDPI, Basel, Switzerland. This article is an open access article distributed under the terms and conditions of the Creative Commons Attribution (CC BY) license (http://creativecommons.org/licenses/by/4.0/). 